\title{
William H. Chandler (1878-1970)
}

\author{
Adel A. Kader and Cathey Wolpert \\ Department of Pomology, University of California, Davis, CA 95616
}

William H. Chandler was born on 31 July 1878 in Butler, Mo. He attended the Univ. of Missouri, Columbia, where he received his BS, MS, and PhD in agriculture in 1905 , 1906, and 1914, respectively.

Chandler's career led him from the Univ. of Missouri, Columbia, to the Univ. of California, Berkeley and Davis first, then to Los Angeles and Riverside. His initial appointment at the Univ. of Missouri in 1905 was a fellow in horticulture. In 1906, he accepted the position of assistant in horticulture, which was followed by his appointment of instructor in 1908; by 1910, he was promoted to assistant professor. Chandler moved to Ithaca, N.Y., in 1913, accepting the position of professor of pomology at Cornell Univ. While at Cornell (1920-23), he served the campus administration as vice-director of research.

The Univ. of California was successful in attracting Chandler to the Berkeley campus. In 1923 he accepted the chairmanship in the Dept. of Pomology, for both the Berkeley and Davis campuses. Chandler left Berkeley in 1937 and relocated to the Los Angeles campus. He held the position of assistant dean at UCLA in charge of the Agricultural activities at Los Angeles and Riverside before retiring in 1948 .

Chandler received numerous honors, including his election as President of ASHS in 1921 and vice president of the American Association for the Advancement of Science in 1939. He was elected to membership in the National Academy of Sciences in 1943 and as faculty research lecturer on the UCLA campus in 1944. In 1951, he was recognized by he American Society of Plant Physiologists when the organization awarded him the Charles Reid Barnes Honorary Life Membership. He was elected Fellow of ASHS in 1965.

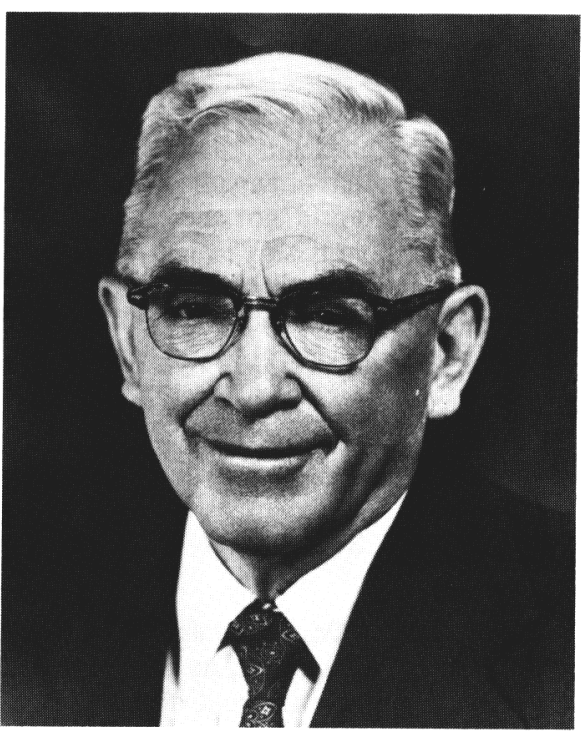

Chandler made outstanding contributions to horticulture and teaching, including the horticultural books Fruit Growing (published in 1925) and North American Orchards: Their Crops and Some of Their Problems (published in 1928). The former, which was 10 years in preparation, is still regarded as a classic in its field. Some of his books were translated into various foreign languages, including Hebrew and Russian. Of major importance are Chandler's later books, entitled Deciduous Orchards and Evergreen Orchards, published in 1942 and 1950, respectively. These books have been used as texts and reference books, and are still used today as very useful and important sources of information.

Chandler was renowned for his discovery that the little-leaf or rosette disease of fruit trees and mottle leaf in citrus was due to a zinc deficiency. This was a discovery of fun- damental importance that led to the development of a routine treatment that is of major economic importance today, and could be said to have been the forerunner of foliar application of nutrients in the broad sense.

Chandler was an important pioneer in controlled studies of woody plant cold hardiness. His publication "The Killing of Plant Tissue by Low Temperature," released in 1913, is considered a classic, as is his review "Cold Resistance in Horticultural Plants," published in the Proceedings of the American Society for Horticultural Science in 1954. The latter set standards for understanding the low temperature problem. It has been said that if one's findings were not consistent with the Chandler view, it was wise to think it through one more time.

Another important contribution, resulting from his studies on bud dormancy, was the effect that environmental factors, particularly chilling, had on dormancy. Chandler was involved in breeding apples with low chilling requirements, resulting in the 'Beverly Hills' apple, successfully grown in southern California and similar climatic regions, and the introduction of 'Caroline', a wisteria that performs well in regions with mild winters. He also investigated pruning fruit trees and ornamentals, plant saps, and polarity and scion rooting.

Chandler's interests were broad, embracing not only all aspects of horticulture, but also everyday affairs of the world. He was an extraordinary horticulturist with strong devotion and personal commitment to research and graduate education. Chandler is remembered for his kindness and sensitivity and the quiet, pervasive, positive influence he had on those around him. By the time of his death on 29 Oct. 1970, Prof. William H. Chandler was recognized as the Dean and Senior Statesman of American Horticulturists. 